


\section{PROSIDING \\ Seminar Nasional Planocosmo}

\section{2 - 13 September 2012}

Editor :

Dr. Petrus Natalivan

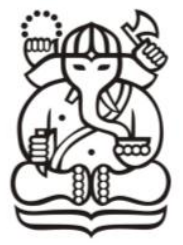

Program Studi Magister Perencanaan Wilayah dan Kota Sekolah Arsitektur, Perencanaan dan Pengembangan Kebijakan Institut Teknologi Bandung 
The Proceeding of Planocosmo National Conference aim to disseminate ideas for information and discussion. Comments or arguments for improvement of their presentation are welcome. The views expressed in the papers are those of the authors and do not necessarily reflect those of the School of Architecture, Planning, and Policy Development.

\section{Editor}

Dr. Petrus Natalivan (editor)

Astri Aulia Safrianty (assistant editor)

Rezky John Ananda (assistant editor)

Cathelya Yosephine Hotasina Silaen (assistant editor)

\section{Cover Design}

Ramanditya Wimbardana

Published by Urban Planning and Design Research Group, School of Architecture, Planning, and Policy Development, Institut Teknologi Bandung

Jalan Ganesha No.10 Bandung 40132, Indonesia

Fax.+62 222501263

(C) 2012

ISBN: 978-602-8763-53

All rights reserved. No part of this publication may be reproduced, stored in a retrieval system or transmitted in any form or by any means, electronic, mechanical, photocopying, recording or otherwise, without the prior written permission of the copyright holder for which application should be addressed in the first instance to the publisher. 


\title{
Pemetaan dan Perencanaan Sanitasi Kota Yogyakarta
}

\author{
Erlis Saputra $^{1}$ \\ Rini Rachmawati \\ Agustina Setyaningrum ${ }^{3}$ \\ M. Isnaini Sadali ${ }^{4}$ \\ ${ }^{1}$ Dosen Program Studi Pembangunan Wilayah \\ Fakultas Geografi, Universitas Gadjah Mada \\ Bulaksumur Yogyakarta 55281 \\ ${ }^{2}$ Mahasiswa Magister Perencanaan dan Pengelolaan \\ Pesisir dan Daerah Aliran Sungai \\ Program Studi S2 Geografi, Universitas Gadjah Mada \\ Bulaksumur Yogyakarta 55281 \\ ${ }^{3}$ Mahasiswa Program Studi Kependudukan, Universitas Gadjah Mada \\ Bulaksumur Yogyakarta 55281 \\ erlissaputra@ugm.ac.id
}

\section{Abstrak}

Millenium Development Goals (MDGs) menempatkan manusia sebagai fokus utama pembangunan yang mencakup kelestarian lingkungan. Salah satu target yang harus dicapai adalah akses berkelanjutan terhadap air minum layak serta akses terhadap sanitasi layak di perkotaan dan perdesaan. Salah satu upaya untuk meningkatkan akses terhadap sanitasi layak Kota Yogyakarta mengadopsi Program Percepatan Pembangunan Sanitasi Pemukiman (PPSP).

Tujuan pertama dari penelitian ini adalah memetakan area beresiko berdasarkan tingkat resiko sanitasi. Proses penentuan area beresiko terhadap kondisi sanitasi dilakukan melalui Indeks Resiko (Risk Index), skoring dan pembobotan, analisis frekuensi (mean weighted) serta diskusi kelompok terfokus (FGD). Penetapan area beresiko dilakukan berdasarkan kriteria: (1) Kepadatan penduduk, (2) Tingkat kemiskinan, (3) Kelurahan yang berada di sepanjang aliran sungai, dan (4) Daerah yang terkena banjir/terdapat genangan air. Tujuan kedua adalah menyusun perencanaan yang sesuai terutama untuk area yang sangat beresiko dan beresiko.

Data yang dikumpulkan dalam penelitian ini meliputi data primer dan data sekunder. Data primer diperoleh dari hasil wawancara (interview) dengan masyarakat Kota Yogyakarta dan, pengamatan/observasi lapangan. Selain data primer, juga dikumpulkan data sekunder yaitu data yang diperoleh dari instansi pemerintahan yang terkait dengan sanitasi. Data-data yang diperoleh selanjutnya diolah dengan menggunakan software SPSS dan ArcGiss dan dianalisis dengan menggunakan pendekatan deskriptif kuantitatif serta analisis spasial untuk mengetahui kondisi sanitasi wilayah secara keruangan.

Hasil dari penelitian ini adalah area beresiko sanitasi Kota Yogyakarta yang dibagi ke dalam 3 area beresiko antara lain area beresiko sangat tinggi meliputi Kelurahan Klutren, Ngampilan, Matrijeron dan Prenggan. Area beresiko sedang antara lain Kelurahan Kricak, Brontokusuman, Bumijo, Pringgokusuman, dan Sorosutan. Area kurang beresiko antara lain Kelurahan Kadipaten. Berdasarkan kondisi ini, selanjutnya disusun program-program perencanaan pembangunan sanitasi khusunya untuk wilayah-wilayah yang sangat beresiko tinggi dan beresiko sedang sehingga dapat mengurangi keberadaan kawasan kumuh perkotaan serta mewujudkan kondisi sanitasi yang sehat di masa mendatang.

Kata Kunci : Perencanaan Sanitasi, Area Beresiko, Kota Yogyakarta

\section{Pendahuluan}

Millenium Development Goals (MDGs) menempatkan manusia sebagai fokus utama pembangunan yang mencakup semua komponen kegiatan yang tujuan akhirnya ialah 
kesejahteraan masyarakat. Di dalam MDGs terdapat 8 tujuan utama, yaitu: 1) memberantas kemiskinan dan kelaparan ekstrim, 2) mewujudkan pendidikan dasar untuk semua, 3) mendorong kesetaraan gender dan pemberdayaan perempuan, 4) menurunkan angka kematian anak, 5) meningkatkan kesehatan ibu, 6) memerangi HIV dan AIDS, malaria serta penyakit lainnya, 7) memastikan kelestarian lingkungan, dan 8) mempromosikan global partnership untuk pembangunan. Seluruh target tersebut harus dicapai pada tahun 2015.

Perencanaan sanitasi yang berkaitan dengan tujuan ketujuh target pencapaian MDGs, memiliki tujuan untuk menurunkan hingga setengahnya proporsi rumah tangga tanpa akses berkelanjutan terhadap air minum layak dan sanitasi layak. Kondisi demikian dapat diukur dengan indikator: a) proporsi rumah tangga dengan akses berkelanjutan terhadap air minum layak, perkotaan dan perdesaan, dan b) proporsi rumah tangga dengan akses berkelanjutan terhadap sanitasi layak, perkotaan dan perdesaan.

Target yang harus dicapai oleh kota-kota di Indonesia pada tahun 2015 adalah agar rumah tangga perkotaan dapat mengakses air bersih sebesar $75,29 \%$. Keberadaan akses air bersih pada tahun 1993 mencapai 50,58\%, sedangkan pada tahun 2009 persentasenya menurun menjadi 49,82\% (PPSP, 2010). Hal ini menunjukkan terjadinya degradasi lingkungan yang menyebabkan air bersih susah ditemukan di kawasan perkotaan. Oleh karena itu, peningkatan akses rumah tangga terhadap air bersih menjadi pekerjaan yang besar bagi pemerintah. Demikian juga halnya dengan peningkatan akses sanitasi lainnya. Target yang dicanangkan pemerintah terhadap akses sanitasi layak perkotaan pada tahun 2015 adalah sebesar $76,82 \%$ dengan acuan dasar 53,64\% pada tahun 1993 . Pada tahun 2009 persentase yang sudah dicapai sebesar 69,51\% rumah tangga dapat memperoleh akses terhadap sanitasi layak pada kawasan perkotaan (PPSP, 2010).

Di Indonesia, salah satu upaya untuk meningkatkan akses terhadap sanitasi layak perkotaan adalah adanya Program Percepatan Pembangunan Sanitasi Pemukiman (PPSP). Program Percepatan Pembangunan Sanitasi Pemukiman (PPSP) mengharuskan setiap kabupaten/kota memiliki dokumen perencanaan sanitasi. Kota Yogyakarta merupakan salah satu kota yang terlibat dalam kegiatan PPSP ini. Sektor sanitasi perkotaan Kota Yogyakarta meliputi pengelolaan limbah, dranaise dan pengelolaan sampah.

Secara umum, sanitasi mengacu pada penyediaan fasilitas dan layanan untuk pembuangan urin dan tinja yang aman. Sanitasi yang tidak memadai adalah penyebab utama penyakit di seluruh dunia dan sanitasi diketahui memiliki dampak positif bagi kesehatan baik di lingkungan rumah tangga dan di masyarakat pada umumnya. Kata 'Sanitasi' juga mengacu pada kemampuan menjaga kondisi higienis, melalui layanan pengumpulan sampah dan pembuangan air limbah (WHO, 2012). Sedangkan definisi yang lainnya sanitasi adalah upaya membuang limbah cair domestik dan sampah untuk menjamin kebersihan dan lingkungan hidup sehat, baik di tingkat rumah tangga maupun di lingkungan perumahan (PPSP, 2010).

Sanitasi mencakup cara kerja yang bersih dan aseptik dalam berbagai bidang, meliputi persiapan, pengolahan, penyiapan maupun transpor makanan, kebersihan dan sanitasi ruangan dan alat-alat pengolahan pangan, serta kebersihan dan kesehatan pekerja di bidang pengolahan dan penyajian (Marriot, 1999; Jenie \& Fardiaz, 1989 dalam Damayanthi dkk, 2008).

Akses masyarakat Kota Yogyakarta terhadap air bersih tidak mengalami persoalan yang besar, karena sebagian besar masyarakat tidak kekurangan air pada musim kemarau dan hujan serta tidak mengalami permasalahan terhadap kualitas air bersih. Sedangkan untuk sanitasi, sebagian besar masyarakat memiliki WC/KM sendiri atau paling tidak di lingkungan permukiman terdapat WC/KM umum. Penyaluran limbah sebagian besar 
disalurkan pada septic tank atau jaringan pipa air limbah yang dimiliki pemerintah daerah.Terkait dengan penanganan drainase, hanya $5 \%$ masyarakat yang pernah mengalami banjir di lingkungan permukiman dimana frekuensi banjir tidak sering terjadi dan banjir yang terjadi cepat surut (Bappeda Kota Yogyakarta, 2008).

Untuk menyusun perencanaan sanitasi Kota Yogyakarta sebelumnya perlu dilakukan survei Environmental Health Risk Assessment (EHRA) pada area yang ditetapkan sebagai area beresiko sanitasi di Kota Yogyakarta. Setelah dilaksanakannya survei EHRA maka selanjutnya dilakukan penilaian dan pemetaan sanitasi serta perencanaan sanitasi Kota Yogyakarta.

\section{Tujuan Penelitian}

Penelitian ini bertujuan untuk: 1) memetakan area beresiko berdasarkan tingkat resiko sanitasi, dan 2) menyusun perencanaan yang sesuai untuk area yang sangat beresiko dan beresiko sanitasi.

\section{Metode}

Penelitian ini terdiri dari tiga tahap. Tahap pertama adalah mengumpulkan data primer dan data sekunder. Data primer merupakan data yang diperoleh langsung dari lapangan, diantaranya adalah survei studi Environmenal Health Risk Assessment (EHRA). Data sekunder terkait dengan arsip dan dokumen pelaksanaan pembangunan sanitasi Kota Yogyakarta dan dokumen perencanaan (RPJMD, RTRW, dan Masterplan Drainase).

Guna mendapatkan informasi dari lapangan, maka dilakukan penarikan sampel kelurahan dari 10 kecamatan yang ada di Kota Yogyakarta. Penentuan sepuluh sampel kelurahan ini didasarkan pada beberapa hal sebagai berikut (PPSP, 2012): a) kepadatan penduduk yaitu jumlah penduduk per luas wilayah, b) angka kemiskinan dengan indikator yang datanya mudah diperoleh tapi cukup representatif menunjukkan kondisi sosial ekonomi setiap kecamatan dan/atau kelurahan,c) kelurahan yang berada di sepanjang aliran sungai, dan d) daerah terkena banjir (kelurahan yang memiliki genangan air).

Berdasarkan kriteria di atas, klastering wilayah Kota Yogyakarta menghasilkan kategori klaster, yaitu kecamatan atau kelurahan yang terdapat pada klaster tertentu dianggap memiliki karakteristik yang identik/homogen dalam hal tingkat resiko kesehatannya. Dengan demikian, kelurahan yang menjadi area survei pada suatu klaster akan mewakili kelurahan lainnya yang bukan merupakan area survei pada klaster yang sama.

Tabel 1. Kategori Klaster berdasarkan kriteria indikasi lingkungan berisiko

\begin{tabular}{|l|l|}
\hline \multicolumn{1}{|c|}{ Katagori Klaster } & \multicolumn{1}{c|}{ Kriteria } \\
\hline Klaster 0 & $\begin{array}{l}\text { Wilayah kelurahan yang tidak memenuhi sama sekali kriteria indikasi } \\
\text { lingkungan berisiko. }\end{array}$ \\
\hline Klaster 1 & $\begin{array}{l}\text { Wilayah kelurahan yang memenuhi minimal 1 kriteria indikasi lingkungan } \\
\text { berisiko }\end{array}$ \\
\hline Klaster 2 & $\begin{array}{l}\text { Wilayah kelurahan yang memenuhi minimal 2 kriteria indikasi lingkungan } \\
\text { berisiko }\end{array}$ \\
\hline Klaster 3 & $\begin{array}{l}\text { Wilayah kelurahan yang memenuhi minimal 3 kriteria indikasi lingkungan } \\
\text { berisiko }\end{array}$ \\
\hline Klaster 4 & $\begin{array}{l}\text { Wilayah kelurahan yang memenuhi minimal 4 kriteria indikasi lingkungan } \\
\text { berisiko }\end{array}$ \\
\hline
\end{tabular}

Sumber : Program Percepatan Pembangunan Sanitasi Pemukiman, 2012 
Hasil dari klastering dengan menggunakan kriteria yang sudah ditetapkan oleh Program PPSP, maka diproleh hasil klastering pada tiap-tiap kelurahan di Kota Yogyakarta yang disajikan pada Tabel 2.

Tabel 2 Hasil Prediksi Klustering Area Beresiko Sanitasi Kota Yoyakarta

\begin{tabular}{|c|c|c|l|}
\hline No. & Prediksi Klaster & Jumlah & \multicolumn{1}{c|}{ Nama Kelurahan } \\
\hline 1 & 4 & 5 & Tegalrejo, Terban, Pakuncen, Ngupasan, Brontokusuman, \\
\hline 2 & 3 & 18 & $\begin{array}{l}\text { Kricak, Karagwaru, Bener, Bumijo, Gowongan, Suryatmajan, } \\
\text { Tegalpanggung, Pringgokusuman, Notoprajan, Purwokinanti, } \\
\text { Wirobrajan, Patangpuluhan, Gedongkiwo, Panembahan, } \\
\text { Keparakan, Wirogunan, Pandeyan, Sorosutan }\end{array}$ \\
\hline 3 & 2 & 17 & $\begin{array}{l}\text { Cokrodiningratan, Demangan, Klitren, Sosromenduran, } \\
\text { Ngampilan, Gunungketur, Mantrijeron, Patehan, Prawirodirjan, } \\
\text { Semaki, Muja-Muju, Tahunan, Warungboto, Giwangan, } \\
\text { Rejowinangun, Prenggan }\end{array}$ \\
\hline 4 & 1 & 5 & Baciro, Bausasran, Suryodiningratan, Kadipaten, Purbayan \\
\hline
\end{tabular}

Sumber : Pokja Sanitasi Kota Yogyakarta, 2012

Jumlah sampel untuk tiap kelurahan diambil sebesar 40 responden. Sementara itu jumlah sampel RT per Kelurahan diambil 8 RT yang dipilih secara acak dan mewakili semua RT yang ada dalam Kelurahan tersebut. Jumlah responden per Kelurahan sebanyak 40 rumah tangga yang harus tersebar secara proporsional di 8 RT terpilih dan pemilihan responden juga secara acak, sehingga diperoleh 5 responden per RT. Berdasarkan kaidah statistik, untuk menentukan jumlah sampel minimum dalam skala kota digunakan "Rumus Slovin" sebagai berikut:

$$
n=\frac{N}{N \cdot d^{2}+1}
$$

Dimana:

$\boldsymbol{n}$ adalah jumlah sampel

$\boldsymbol{N}$ adalah jumlah populasi

$\boldsymbol{d}$ adalah persentase toleransi ketidaktelitian karena kesalahan pengambilan sampel yang masih dapat ditolerir $5 \%(d=0,05) \rightarrow$ Asumsi tingkat kepercayaan $95 \%$, karena menggunakan $\alpha=0,05$, sehingga diperoleh nilai $Z=1,96$ yang kemudian dibulatkan menjadi $Z=2$.

Dengan jumlah populasi Kota Yogyakarta tahun 2010 sebanyak 388.627 jiwa, maka jumlah sampel minimum yang harus dipenuhi adalah sebanyak 400 . Oleh karena itu, jumlah kelurahan yang akan dijadikan target area survei sebanyak 10 kelurahan dan untuk masingmasing kelurahan diambil 40 responden. Sehingga jumlah sampel diambil sebanyak $10 \times 40$ $=400$ responden.

Setelah menghitung kebutuhan responden dengan menggunakan Rumus Slovin, maka ditentukan lokasi studi EHRA dengan cara memilih sebanyak 10 kelurahan secara random. Hasil pemilihan ke-10 kelurahan tersebut disajikan pada tabel berikut:

Tabel 3. Kelurahan Terpilih Studi EHRA Kota Yogyakarta tahun 2012

\begin{tabular}{|c|l|l|c|c|c|}
\hline No & Kelurahan Terpilih & Kecamatan & $\begin{array}{c}\text { Prediksi } \\
\text { Kluster }\end{array}$ & $\begin{array}{c}\text { Jumlah RT } \\
\text { terpilih }\end{array}$ & $\begin{array}{c}\text { Jumlah } \\
\text { Responden }\end{array}$ \\
\hline 1 & Brontokusuman & Mergangsan & 4 & 8 & 40 \\
\hline 2 & Kricak & Tegal rejo & 3 & 8 & 40 \\
\hline
\end{tabular}




\begin{tabular}{|c|l|l|c|c|c|}
\hline No & Kelurahan Terpilih & Kecamatan & $\begin{array}{c}\text { Prediksi } \\
\text { Kluster }\end{array}$ & $\begin{array}{c}\text { Jumlah RT } \\
\text { terpilih }\end{array}$ & $\begin{array}{c}\text { Jumlah } \\
\text { Responden }\end{array}$ \\
\hline 3 & Bumijo & Jetis & 3 & 8 & 40 \\
\hline 4 & Pringgokusuman & Gedongtengen & 3 & 8 & 40 \\
\hline 5 & Sorosutan & Umbulharjo & 3 & 8 & 40 \\
\hline 6 & Klitren & Gondokusuman & 2 & 8 & 40 \\
\hline 7 & Ngampilan & Ngampilan & 2 & 8 & 40 \\
\hline 8 & Mantrijeron & Mantrijeron & 2 & 8 & 40 \\
\hline 9 & Prenggan & Kotagede & 2 & 8 & 40 \\
\hline 10 & Kadipaten & Kraton & 1 & 8 & 40 \\
\hline
\end{tabular}

Sumber : Pokja Sanitasi Kota Yogyakarta, 2012

Tahap kedua adalah penilaian dan pemetaan kondisi sanitasi Kota Yogyakarta. Pada tahap ini, data primer yang sudah dikumpulkan kemudian diolah dengan menggunakan software SPSS dan ArcGISS. Data yang sudah diolah ini selanjutnya dianalisis dengan analisis deskriptif kuantitatif dan analisis spasial untuk mengetahui kelurahan yang beresiko sanitasi dan penyebab utama permasalahan sanitasi Kota Yogyakarta.

Tahap ketiga adalah penyusunan perencanaan sanitasi Kota Yogyakarta. Perencanaan sanitasi ini didasarkan pada kondisi sanitasi Kota Yogyakarta serta program kerja sektor sanitasi tahun 2012.

\section{Hasil dan Diskusi}

\subsection{Kondisi Sanitasi Kota Yogyakarta}

\subsubsection{Persampahan}

Pengelolaan sampah Kota Yogyakarta sebesar 52\% dilakukan dengan pengangkutan menuju TPA (Tempat Pembuangan Akhir) Piyungan. TPA Piyungan merupakan TPA yang digunakan secara bersama oleh Kota Yogyakarta, Kabupaten Sleman, dan Kabupaten Bantul. Kerjasama pengelolaan sampah tersebut merupakan salah satu bentuk dari kerjasama pengembangan dan pengelolaan kawasan perkotaan yang tergabung dalam sekretariat KARTMANTUL (Yogyakarta, Sleman, Bantul). Sisa sampah yang dihasilkan Kota Yogyakarta sebesar $42 \%$ diolah dengan cara dibakar ataupun pengolahan lain melalui mekanisme 3R (Reuse, Reduce, Recycle).

Berdasarkan hasil pengukuran EHRA, permasalahan persampahan cukup banyak ditemui. Keberadaan tikus yang berkeliaran di sekitar tempat sampah dan di saluran drainase merupakan masalah yang paling banyak dikeluhkan oleh penduduk, yaitu sekitar $35 \%$. Selain keberadaan tikus, tumpukan sampah yang dapat menampung air menjadi sarang bagi nyamuk dan merupakan masalah persampahan berikutnya yang dianggap penting oleh sekitar 19\% penduduk. Berikut disajikan persentase kondisi dan permasalahan sampah di lingkungan RT/RW Kota Yogyakarta (lihat Gambar 1). 


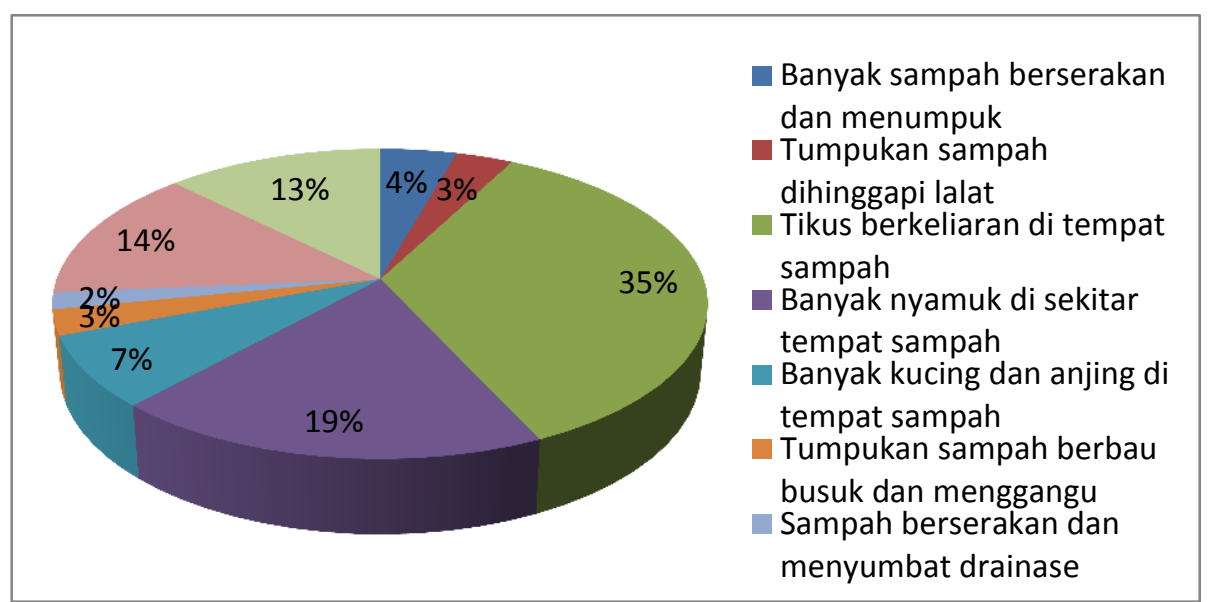

Gambar 1. Diagram kondisi dan permasalahan sampah di lingkungan RT/RW

Kota Yogyakarta

(Sumber : Pokja Sanitasi Kota Yogyakarta, 2012)

Pengelolaan sampah rumah tangga di Kota Yogyakarta umumnya dilakukan dengan mengumpulkan sampah di untuk dibuang ke TPS. Cara pengelolaan sampah tersebut dilakukan sebanyak $88 \%$ penduduk yang tinggal di wilayah sampel. Selain metode pengolahan dengan cara tersebut, pengelolaan sampah dilakukan dengan cara mengumpulkan ke kolektor informal dan dengan cara membakar. Kolektor informal tersebut umumnya adalah para pengepul sampah yang cukup banyak terdapat di Kota Yogyakarta. Berdasarkan pendataan yang dilakukan oleh Badan Lingkungan Hidup, di Kota Yogyakarta terdapat sekitar 50 pengepul yang tersebar di berbagai titik.

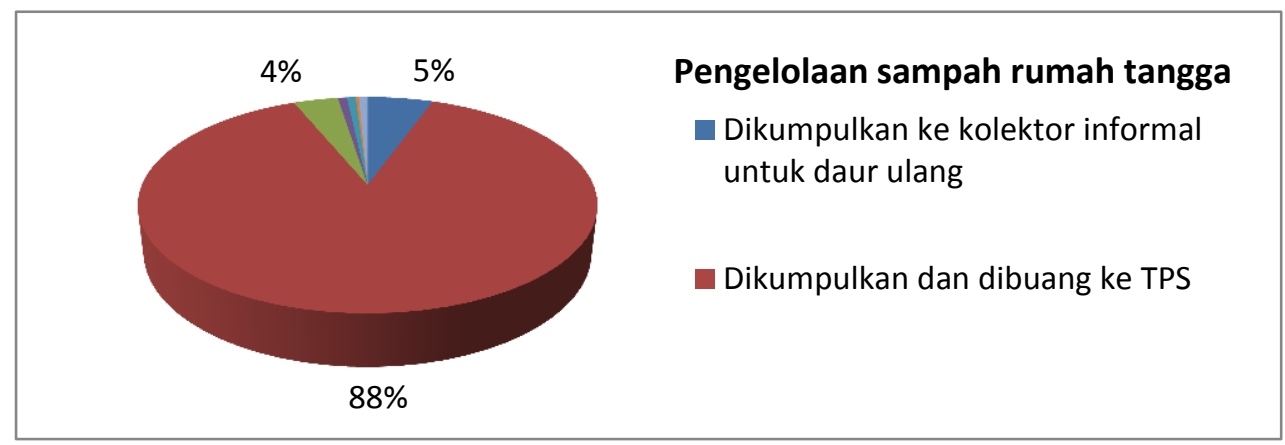

Gambar 2. Metode Pengelolaan sampah rumah tangga Kota Yogyakarta

(Sumber : Pokja Sanitasi Kota Yogyakarta, 2012)

Wadah yang digunakan sebagai pengumpul sampah di tingkat rumah tangga cukup beragam. Berdasarkan hasil studi EHRA, keranjang sampah terbuka merupakan wadah pengumpul sampah yang paling banyak digunakan oleh penduduk. Persentase penggunaan keranjang sampah terbuka adalah sebesar 33\%, lebih besar dibanding kantong plastik terbuka (25\%), kantong plastik tertutup (20\%) dan keranjang sampah tertutup (18\%) (lihat Gambar 3). Sementara itu hanya $4 \%$ rumah tangga sampel yang tidak memiliki wadah penampungan sampah di tingkat rumah tangga. Dalam pengangkutan sampah menuju TPS, sebagian besar penduduk menggunakan jasa petugas pengangkut sampah. Hanya $14 \%$ persen dari penduduk yang membuang sampah sendiri ke TPS. 


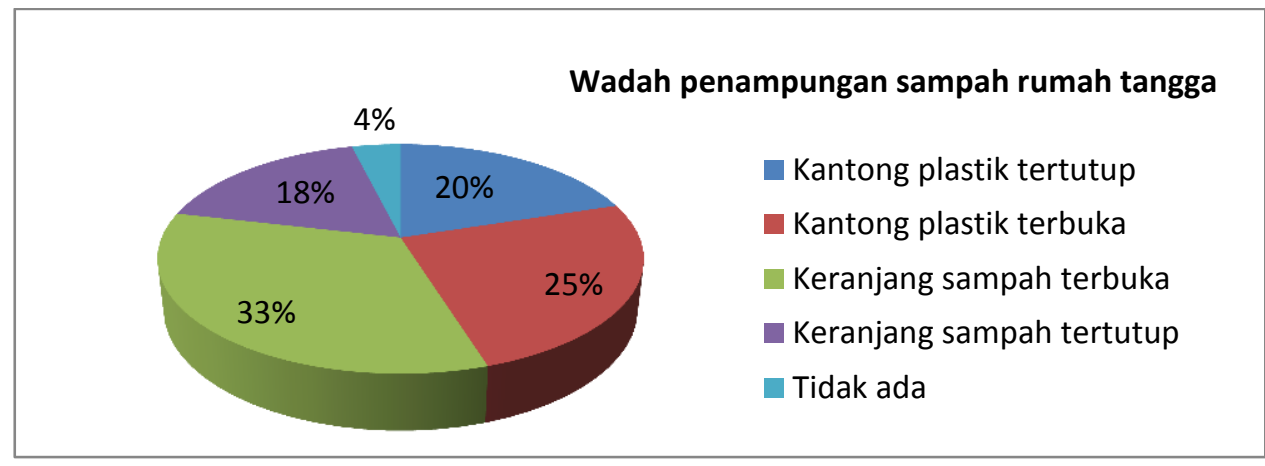

Gambar 3. Wadah Penampungan sampah yang digunakan warga

Kota Yogyakarta

(Sumber : Pokja Sanitasi Kota Yogyakarta, 2012)

Berdasarkan hasil survei di wilayah sampel, jenis sampah yang paling banyak dikumpulkan ke kolektor informal untuk di daur ulang adalah kertas, yaitu sebanyak $32 \%$ (lihat Gambar 4). Kertas berupa koran bekas, kardus barang, ataupun bekas laporan kantor dan mahasiswa masih memiliki nilai jual yang cukup bagus, dan diterima oleh para pengepul. Dalam pengangkutan sampah menuju TPS, sebagian besar penduduk menggunakan jasa petugas pengangkut sampah. Hanya 14\% persen dari penduduk yang membuang sampah sendiri ke TPS.

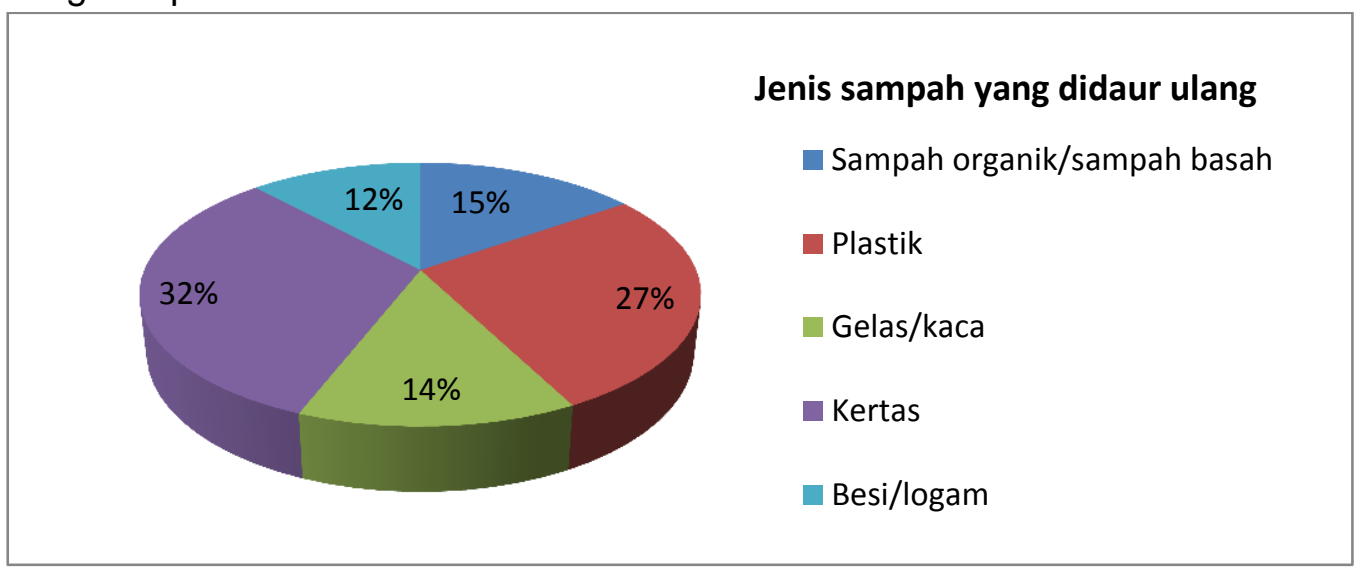

Gambar 4. Jenis Sampah yang di daur ulang

(Sumber : EHRA, 2012)

\subsubsection{Limbah}

Sebagian besar rumah tangga penduduk yang tinggal di wilayah sampel memanfaatkan jamban pribadi yang terdapat di dalam masing-masing rumah untuk melakukan buang air besar. Hanya $8 \%$ yang memanfaatkan MCK/WC umum untuk aktivitas BAB (Buang Air Besar). Tinja dan limbah cair merupakan bahan buangan yang timbul karena adanya kehidupan manusia sebagai mahluk individu maupun makhluk sosial (Harmayani dan Konsukartha, 2007)

Sementara itu berdasarkan pengamatan yang dilakukan oleh penduduk tersebut di lingkungan tempat tinggalnya, hampir semua masyarakat sudah melakukan aktivitas BAB di jamban pribadi atau MCK yang telah disediakan. Kebiasaan buang air besar di tempat terbuka seperti sungai, kebun sudah sangat tidak jamak ditemukan. 


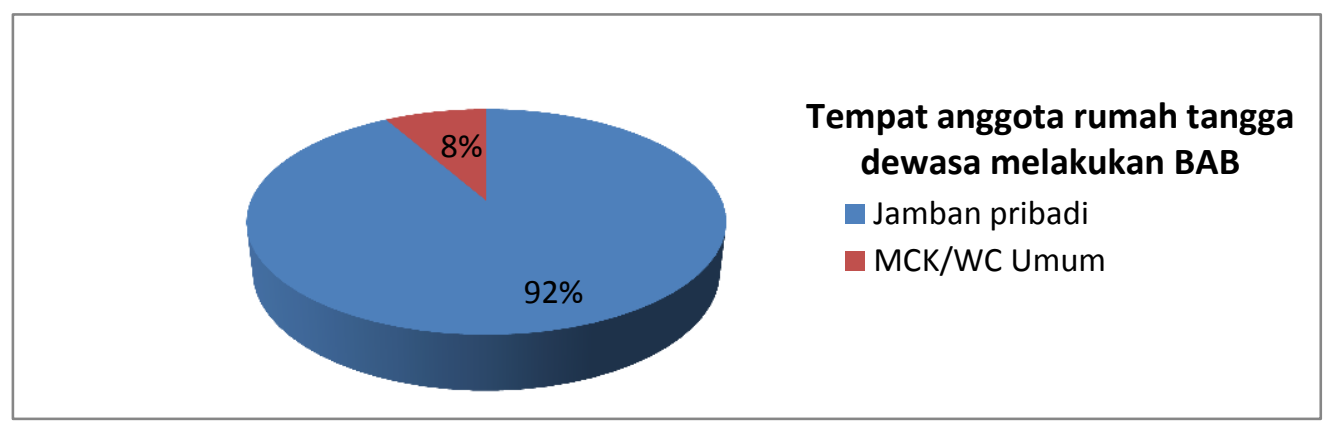

Gambar 5. Tempat Anggota Rumah Tangga Dewasa Melakukan BAB

(Sumber : Pokja Sanitasi Kota Yogyakarta, 2012)

Penduduk yang rumahnya dilengkapi dengan jamban umumnya telah memiliki tangki septik sebagai tempat pembuangan akhir tinja. Jumlah penduduk yang memiliki tangki septik adalah $57 \%$ dari sampel dan sisanya tidak membuang tinja yang dihasilkan ke tangki septik. Sebanyak $29 \%$ penduduk membuang tinja langsung ke saluran drainase. Tangki septik yang dimiliki oleh penduduk sebagian besar (64\%) sudah digunakan lebih dari 10 tahun. Pengurasan tangki septik merupakan salah satu cara yang harus dilakukan dalam rangka perawatan tersebut. Namun, berdasarkan hasil studi EHRA yang dilakukan hampir $60 \%$ tidak pernah melakukan pengurasan terhadap tangki septik yang dimiliki. Hanya sekitar $40 \%$ saja tangki septik yang pernah dikuras selama pemakaiannya (lihat Gambar 6).

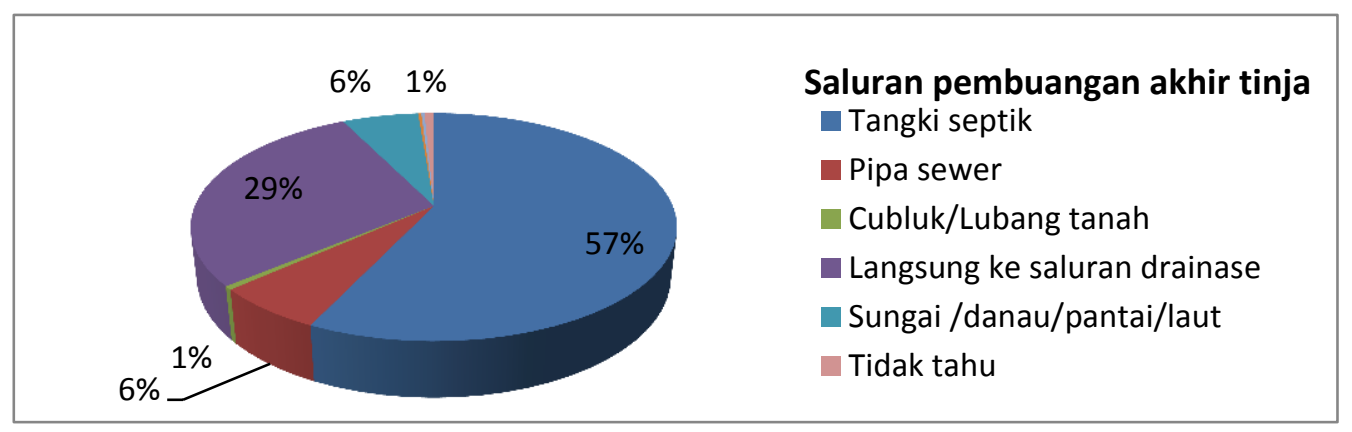

Gambar 6. Saluran Pembuangan Akhir Tinja

(Sumber : EHRA, 2012)

\subsubsection{Drainase Lingkungan Sekitar Rumah dan Banjir}

Sistem drainase di Kota Yogyakarta masih mengandalkan sistem pembuangan air permukaan ke sungai/anak sungai, baik dari lingkungan permukiman maupun daerah terbangun lain, menuju ke saluran-saluran air hujan kemudian dibuang ke sungai dan akhirnya ke laut.

Saluran drainase yang berada di sekitar rumah tangga menggunakan saluran terbuka dan tertutup baik yang dialirkan ke sungai maupun sumur resapan yang telah ada. Berdasarkan hasil survei yang dilaksanakan pada 400 responden di Kota Yogyakarta, jumlah rumah tangga yang memiliki sarana pembuangan air limbah sejumlah $81,4 \%$ (atau 316 rumah tangga). Hasil tersebut merupakan kondisi eksisting rumah tangga yang berada dalam wilayah yang yang tergolong padat penduduk, miskin dan berada di sekitar sungai di Kota Yogyakarta. Dengan demikian kesadaran masyarakat dalam pembuangan air limbah rumah tangga selain tinja sudah bagus, karena hampir seluruh rumah tangga memliki sarana pembuangan air limbah, untuk lebih jelasnya dapat dilihat pada Gambar 7 sebagai berikut. 


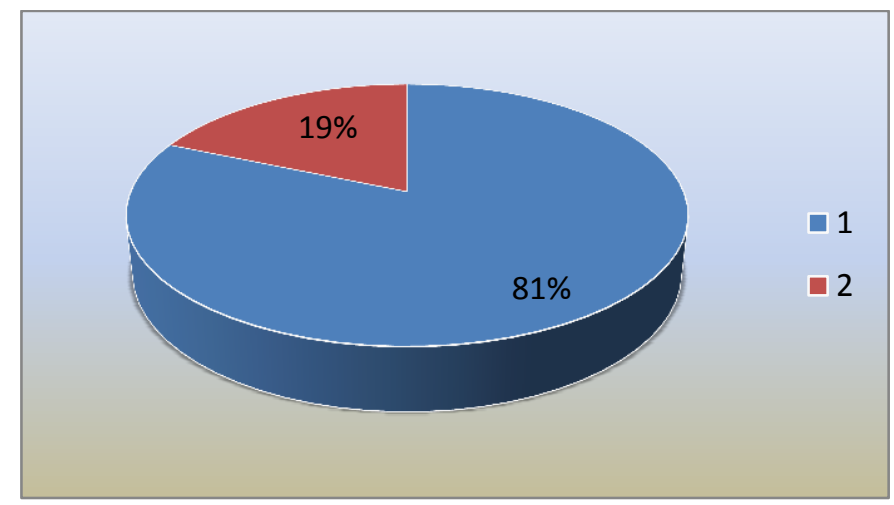

Ket: 1 = memiliki pembuangan air limbah; 2 - tidak memiliki pembuangan air limbah Gambar 7. Rumah Tangga yang Memiliki Sarana Pembuangan Air Limbah Selain Tinja (SPAL = Saluran Pembuangan Air Limbah) (Sumber : Pokja Sanitasi Kota Yogyakarta, 2012).

Tujuan Pembuangan air bekas buangan/air limbah selain tinja dibuang ke saluran tertutup yang sudah ada. Saluran drainase tertutup yang ada di Kota Yogyakarta sudah terbangun dan dioptimalkan oleh para penduduk sebagai saluran pembuangan air bekas/limbah selain tinja. Terbukti bahwa sebagian besar responden menjawab bahwa air bekas buangan/limbah selain tinja yang berasal dari dapur, kamar mandi dan tempat cuci pakaian sudah banyak yang disalurkan ke saluran tertutup yang sudah ada. Hal ini dapat dilihat pada jumlah rumah tangga yang membuang air bekas/limbah ke saluran tertutup lebih dari 200 responden (rumah tangga).

Kejadian banjir di Kota Yogyakarta tergolong sangat rendah atau hanya terjadi di beberapa lokasi yang berada di daerah sekitar sungai (atau bantaran sungai). Hal ini ditunjukkan oleh jawaban responden (rumah tangga) yang sebagian besar (93\%) tidak pernah terjadi banjir, baik hingga ke rumah, lingkungan dan jalan sekitar rumah, hal ini dapat dilihat pada Gambar 8 berikut ini.

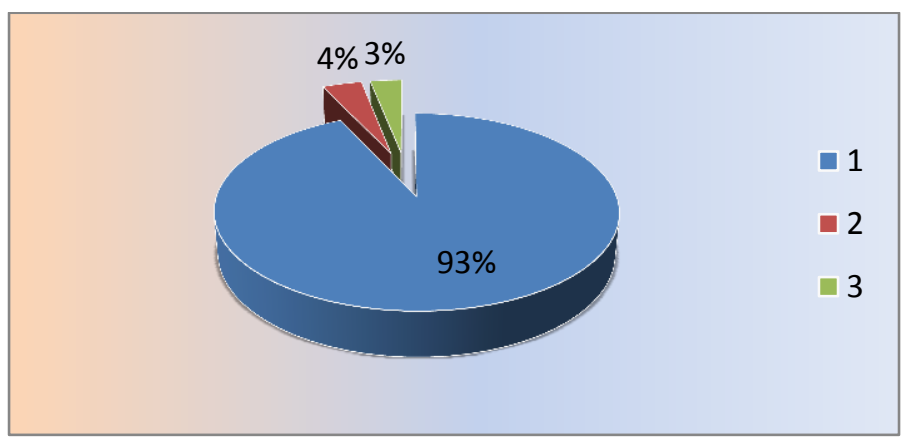

Ket: 1 = Tidak pernah; 2 = Sekali dalam setahun; 3 = Beberapa kali dalam setahun Gambar 8. Intensitas Kejadian Banjir yang Terjadi di Rumah, Lingkungan dan Jalan di Sekitar Tempat Tinggal

(Sumber : Pokja Sanitasi Kota Yogyakarta, 2012)

Berdasarkan hasil survei yang telah dilakukan dalam penyusunan study EHRA, maka dapat diketahui jumlah kejadian banjir terakhir hanya menimpa 41 rumah tangga dari total 400 rumah tangga yang disurvei. Beberapa rumah tangga yang terkena banjir, tinggi air yang masuk ke dalam rumah berkisar dari setumit hingga sepinggang orang dewasa. Pada Gambar 9, kejadian terbanyak (38\% dari 41 rumah tangga yang terkena banjir) adalah banjir dengan ketinggian air setengah lutut orang dewasa. Kejadian banjir yang terjadi pada 
sebagian warga di Kota Yogyakarta tidak selalu merendam WC atau kamar mandi warga, sehingga tidak merusak saluran pembuangan yang berasal dari WC atau kamar mandi. Sebagian besar genangan yang terjadi saat banjir akan mengering lagi dalam waktu 1-3 jam.

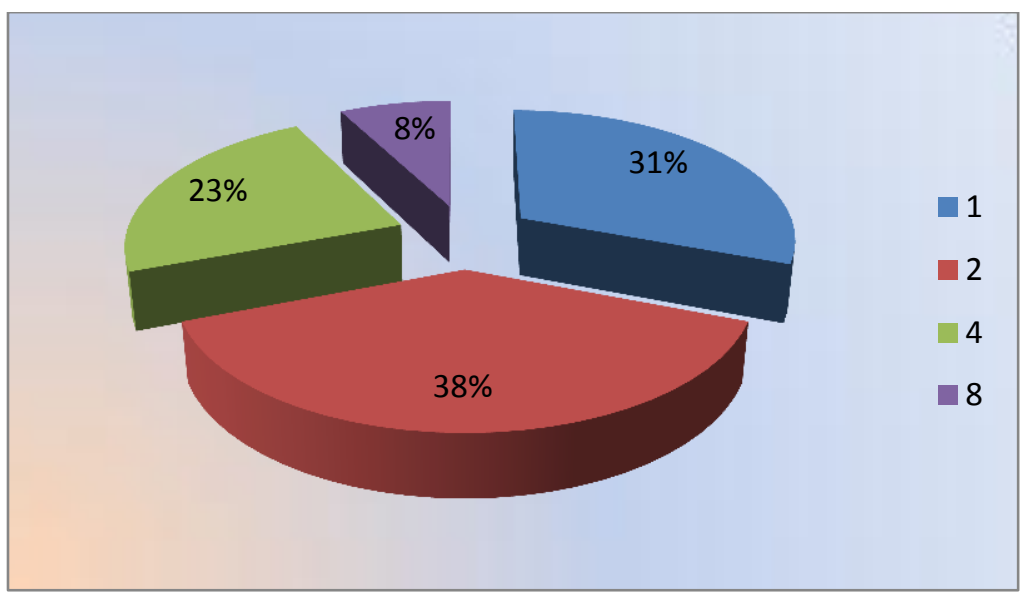

Ket: 1 = Setumit orang dewasa; 2 = Setengah lutut orang dewasa; 3 = Selutut orang dewasa; 4 = Sepinggang orang dewasa; 8 = Tidak tahu

Gambar 9. Ketinggian Air yang Masuk ke Rumah Akibat Banjir (Sumber : Pokja Sanitasi Kota Yogyakarta, 2012)

\subsubsection{Pengelolaan Air Bersih Rumah Tangga}

Pengelolaan air bersih rumah tangga meliputi akses terhadap sumber air bersih, pengolahan serta penyimpanan dan penanganan air yang baik dan aman. Sumber air bersih yang digunakan oleh masyarakat Kota Yogyakarta beragam, mulai dari air bersih yang bersumber dari air botol kemasan, air isi ulang, air ledeng, air PDAM, air sumur bor, air sumur gali terlindungi dan tidak terlindungi, air sungai, dan sumber air lainnya. Dari berbagai sumber air bersih yang digunakan, 60\% masyarakat Kota Yogyakarta menggunakan air bersih yang berasal dari sumur gali terlindungi (lihat Gambar 10).

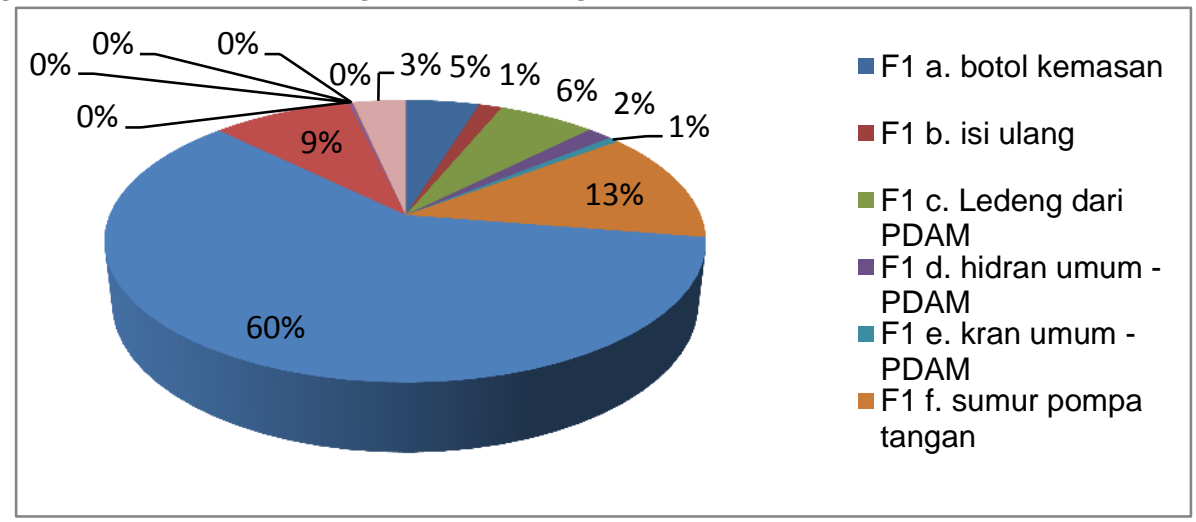

Gambar 11. Sumber Air Bersih Warga Kota Yogyakarta

(Sumber : Pokja Sanitasi Kota Yogyakarta, 2012)

Untuk kebutuhan minum dan memasak, masyarakat Kota Yogyakarta mayoritas juga menggunakan air bersih yang berasal dari sumur gali terlindungi. Diantara masyarakat juga ada yang menggunakan sumur gali tidak terlindungi dan air bersih yang berasal dari PDAM. Berdasarkan hasil survei EHRA, sumber air bersih utama masyarakat Kota Yogyakarta untuk kebutuhan air minum, memasak, mencuci piring, gelas dan pakaian serta menggosok gigi antara lain berasal dari sumur gali terlindungi, air PDAM, sumur gali tidak terlindungi, 
sumur pompa tangan, air botol kemasan, serta air isi ulang. Terkait dengan kualitas sumber air yang digunakan, 92\% masyarakat puas dengan kualitas sumber air yang digunakan (Gambar 12).

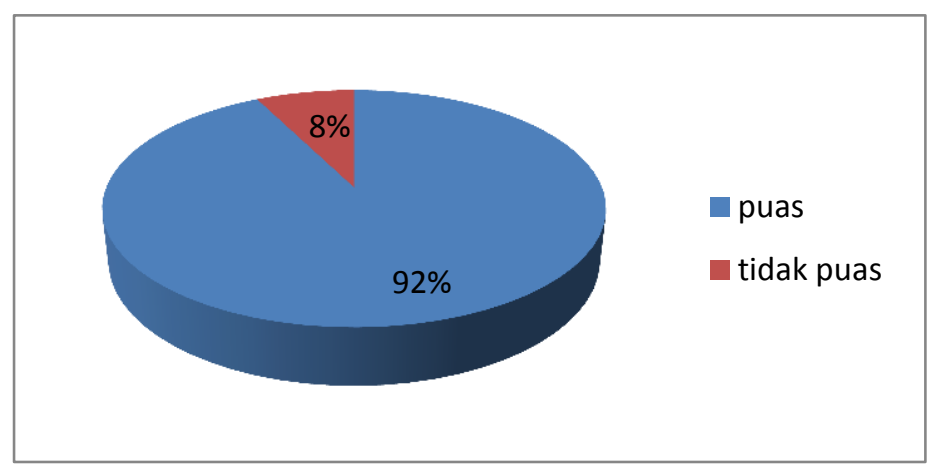

Gambar 12 Grafik Kepuasan Terhadap Kualitas Air (Sumber : Pokja Sanitasi Kota Yogyakarta, 2012)

Masyarakat Kota Yogyakarta merebus air bersih yang diperoleh. Setelah air tersebut diolah selanjutnya air disimpan di dalam wadah penyimpanan antara lain disimpan di dalam panci tertutup, teko/ceret/ketel, botol/termos, dan atau galon. Mayoritas masyarakat menyimpan air tersebut di dalam botol/termos yaitu sebanyak $56 \%$.

\subsection{Kelurahan Beresiko Sanitasi Kota Yogyakarta}

Kelurahan yang menjadi wilayah penelitian untuk area beresiko meliputi Kelurahan Brontokusuman, Kricak, Bumijo, Pringgokusuman, Sorosutan, Klitren, Matrijeron, Prenggan dan Kadipaten. Berikut disajikan indeks resiko sanitasi hasil survey Environmental Health Risk Assessment (EHRA) Kota Yogyakarta tahun 2012 (Tabel 4).

Tabel 4. Indeks Resiko Sanitasi Kota Yogyakarta Tahun 2012

\begin{tabular}{|c|c|c|c|c|c|c|}
\hline \multirow[b]{2}{*}{ Variabel } & \multirow[b]{2}{*}{ Jawaban } & \multicolumn{5}{|c|}{ Klaster } \\
\hline & & 1 & 2 & 3 & 4 & $\begin{array}{l}\text { Tota } \\
\text { I }\end{array}$ \\
\hline \multicolumn{7}{|l|}{ 1. SUMBER AIR } \\
\hline 1.1. Sumber air terlindungi & Tidak & $\begin{array}{r}100 . \\
0\end{array}$ & $\begin{array}{r}100 . \\
0\end{array}$ & $\begin{array}{r}100 . \\
0\end{array}$ & $\begin{array}{r}100 . \\
0\end{array}$ & .0 \\
\hline $\begin{array}{l}\text { 1.2. Penggunaan sumber air tidak } \\
\text { terlindungi. }\end{array}$ & Ya & 7.5 & 8.1 & 10.0 & .0 & \\
\hline 1.3. Kelangkaan air & $\mathrm{Ya}$ & .0 & 1.9 & .0 & .0 & \\
\hline \multicolumn{7}{|l|}{ 2. AIR LIMBAH DOMESTIK } \\
\hline 2.1. Tangki septik suspek aman & Tidak & 17.5 & 47.5 & 45.0 & 32.5 & \\
\hline $\begin{array}{l}\text { 2.2. Pencemaran karena pembuangan isi } \\
\text { tangki septik }\end{array}$ & Ya & 50.0 & 35.3 & 43.2 & 50.0 & \\
\hline 2.3. Pencemaran karena SPAL & $\mathrm{Ya}$ & 10.0 & 17.5 & 10.6 & 45.0 & \\
\hline \multicolumn{7}{|l|}{ 3. PERSAMPAHAN } \\
\hline 3.1. Pengelolaan sampah & Tidak & 5.0 & 10.0 & 12.5 & 7.5 & \\
\hline 3.2. Frekuensi pengangkutan sampah & Tidak memadai & .0 & 55.6 & .0 & .0 & \\
\hline $\begin{array}{l}\text { 3.3. 3.3 Ketepatan waktu pengangkutan } \\
\text { sampah }\end{array}$ & $\begin{array}{l}\text { Tidak tepat } \\
\text { waktu }\end{array}$ & .0 & 33.3 & 30.0 & .0 & \\
\hline 3.4. Pengolahan sampah setempat & Tidak diolah & 92.5 & 91.9 & 86.9 & 92.5 & \\
\hline
\end{tabular}




\begin{tabular}{|c|c|c|c|c|c|c|}
\hline \multirow[b]{2}{*}{ Variabel } & \multirow[b]{2}{*}{ Jawaban } & \multicolumn{5}{|c|}{ Klaster } \\
\hline & & \multirow[t]{2}{*}{1} & \multirow[t]{2}{*}{2} & \multirow[t]{2}{*}{3} & \multirow[t]{2}{*}{4} & \multirow[t]{2}{*}{$\begin{array}{l}\text { Tota } \\
\text { I }\end{array}$} \\
\hline 4. GENANGAN AIR & & & & & & \\
\hline 4.1. Adanya genangan air & $\mathrm{Ya}$ & 7.5 & 29.4 & 9.4 & 17.5 & \\
\hline 5. PERILAKU HIDUP BERSIH SEHAT & & & & & & \\
\hline 5.1. CTPS di lima waktu penting & Tidak & 82.5 & 56.9 & 82.5 & $\begin{array}{r}100 . \\
0\end{array}$ & \\
\hline $\begin{array}{l}\text { 5.2. a. Apakah lantai dan dinding jamban } \\
\text { bebas dari tinja? }\end{array}$ & Tidak & 7.5 & 14.4 & 15.0 & .0 & \\
\hline $\begin{array}{l}\text { 5.2.b. Apakah jamban bebas dari kecoa dan } \\
\text { lalat? }\end{array}$ & Tidak & 5.0 & 15.0 & 33.1 & 2.5 & \\
\hline 5.2.c. Keberfungsian penggelontor. & Tidak & 7.5 & 15.6 & 5.0 & .0 & \\
\hline $\begin{array}{l}\text { 5.2.d. Apakah terlihat ada sabun di dalam } \\
\text { atau di dekat jamban? }\end{array}$ & Tidak & 17.5 & 11.9 & 6.3 & .0 & \\
\hline $\begin{array}{l}\text { 5.3. Pencemaran pada wadah penyimpanan } \\
\text { dan penanganan air }\end{array}$ & Ya, tercemar & 57.5 & 7.5 & 28.1 & 7.5 & \\
\hline 5.4. Perilaku BABS & Ya, BABS & 90.0 & 60.6 & 76.9 & 92.5 & \\
\hline
\end{tabular}

Sumber: Hasil Pengolahan Data, 2012

Masing-masing nilai indeks resiko sub sektor sanitasi tersebut kemudian di bobot untuk menyamakan satuan. Berikut disajikan hasil pembobotan indeks resiko sanitasi (Tabel 5).

Tabel 5 Pembobotan Indeks Resiko Sanitasi Kota Yogyakarta

\begin{tabular}{|c|c|c|c|c|c|}
\hline \multirow{2}{*}{\multicolumn{6}{|c|}{$\begin{array}{r}\text { Variabel } \\
\text { 1. SUMBER AIR }\end{array}$}} \\
\hline & & & & & \\
\hline 1.1. Sumber air tercemar & $25 \%$ & 25 & 25 & 25 & 25 \\
\hline $\begin{array}{l}\text { 1.2. Penggunaan sumber air tidak } \\
\text { terlindungi. }\end{array}$ & $25 \%$ & 2 & 2 & 3 & - \\
\hline 1.3. Kelangkaan air & $50 \%$ & - & 1 & - & - \\
\hline Jumlah & & 27 & 28 & 28 & 25 \\
\hline \multicolumn{6}{|l|}{ 2. AIR LIMBAH DOMESTIK } \\
\hline 2.1. Tangki septik suspek aman & $33 \%$ & 6 & 16 & 15 & 11 \\
\hline $\begin{array}{l}\text { 2.2. Pencemaran karena } \\
\text { pembuangan isi tangki septik }\end{array}$ & $33 \%$ & 17 & 12 & 14 & 17 \\
\hline 2.3. Pencemaran karena SPAL & $33 \%$ & 3 & 6 & 4 & 15 \\
\hline Jumlah & & 26 & 33 & 33 & 43 \\
\hline \multicolumn{6}{|l|}{ 3. PERSAMPAHAN } \\
\hline 3.1. Pengelolaan sampah & $25 \%$ & 1 & 3 & 3 & 2 \\
\hline $\begin{array}{l}\text { 3.2. Frekuensi pengangkutan } \\
\text { sampah }\end{array}$ & $25 \%$ & - & 14 & - & - \\
\hline $\begin{array}{l}\text { 3.3. Ketepatan waktu } \\
\text { pengangkutan sampah }\end{array}$ & $25 \%$ & - & 8 & 8 & - \\
\hline
\end{tabular}




\begin{tabular}{|c|c|c|c|c|c|}
\hline Variabel & Bobot & Cluster 1 & Cluster 2 & Cluster 3 & Cluster 4 \\
\hline 3.4. Pengolahan setempat & $25 \%$ & 23 & 23 & 22 & 23 \\
\hline Jumlah & & 24 & 48 & 32 & 25 \\
\hline 4. GENANGAN AIR & & & & & \\
\hline 4.1. Adanya genangan air & $100 \%$ & 8 & 29 & 9 & 18 \\
\hline Jumlah & & 8 & 29 & 9 & 18 \\
\hline $\begin{array}{l}\text { 5. PERILAKU HIDUP BERSIH } \\
\text { SEHAT }\end{array}$ & & 60 & 35 & 51 & 50 \\
\hline 5.1. CTPS di lima waktu penting & $25 \%$ & 21 & 14 & 21 & 25 \\
\hline $\begin{array}{l}\text { 5.2.a. Apakah lantai dan dinding } \\
\text { jamban bebas dari tinja? }\end{array}$ & $6 \%$ & 0 & 1 & 1 & - \\
\hline $\begin{array}{l}\text { 5.2.b. Apakah jamban bebas dari } \\
\text { kecoa dan lalat? }\end{array}$ & $6 \%$ & 0 & 1 & 2 & 0 \\
\hline $\begin{array}{l}\text { 5.2.c. Keberfungsian } \\
\text { penggelontor. }\end{array}$ & $6 \%$ & 0 & 1 & 0 & - \\
\hline $\begin{array}{l}\text { 5.2.d. Apakah terlihat ada sabun } \\
\text { di dalam atau di dekat } \\
\text { jamban? }\end{array}$ & $6 \%$ & 1 & 1 & 0 & - \\
\hline $\begin{array}{l}\text { 5.3. Pencemaran pada wadah } \\
\text { penyimpanan dan } \\
\text { penanganan air }\end{array}$ & $25 \%$ & 14 & 2 & 7 & 2 \\
\hline 5.4. Perilaku BABS & $25 \%$ & 23 & 15 & 19 & 23 \\
\hline Jumlah & & 60 & 35 & 51 & 50 \\
\hline Total & & 144 & 173 & 153 & 160 \\
\hline
\end{tabular}

Sumber : Hasil Pengolahan Data, 2012

Nilai indeks resiko sanitasi yang sudah dibobot selanjutnya dikategorisasikan berdasarkan wilayah yang paling beresiko. Untuk pengkategorisasian, digunakan nilai maksimal dan nilai minimal serta batas atas dan batas bawah. Lebih jelasnya bisa dilihat pada Tabel 6 berikut ini.

Tabel 6. Kategorisasi Daerah Beresiko Sanitasi Kota Yogyakarta

\begin{tabular}{|l|r|r|}
\hline & \multicolumn{1}{|c|}{ Batas Nilai Risiko } & \multicolumn{1}{c|}{ Keterangan } \\
\hline Total Indeks Risiko Max & 173 & \\
\hline Total Indeks Risiko Min & 144 & \\
\hline Interval & 7 & \\
\hline Kategori Area Berisiko & \multicolumn{2}{|c|}{ Batas Atas } \\
\hline Kurang Berisiko & 144 & 152 \\
\hline Berisiko Sedang & 153 & 160 \\
\hline Risiko Tinggi & 161 & 176 \\
\hline Risiko Sangat Tinggi & 169 & 176 \\
\hline
\end{tabular}


Hasil kategorisasi ini menunjukkan bahwa terdapat perbedaan daerah beresiko sanitasi yaitu antara prediksi awal dengan kondisi yang sebenarnya dilapangan setelah dilakukan survei EHRA. Berikut disajikan Tabel 7 hasil kategorisasi area beresiko Kota Yogyakarta. agar dapat melihat kondisi sanitasi secara keruangan maka disajikan peta area beresiko sanitasi Kota Yogyakarta pada Gambar 13.

Tabel 7. Hasil Kategorisasi Area Beresiko Kota Yogyakarta

\begin{tabular}{|c|c|l|l|}
\hline No. & Klaster & \multicolumn{1}{|c|}{ Keterangan } & \multicolumn{1}{c|}{ Nama Kelurahan } \\
\hline 1. & 4 & Beresiko sedang & Tegalrejo, Terban, Pakuncen, Ngupasan, Brontokusuman, \\
\hline 2. & 3 & Beresiko sedang & $\begin{array}{l}\text { Kricak, Karagwaru, Bener, Bumijo, Gowongan, Suryatmajan, } \\
\text { Tegalpanggung, Pringgokusuman, Notoprajan, Purwokinanti, } \\
\text { Wirobrajan, Patangpuluhan, Gedongkiwo, Panembahan, } \\
\text { Keparakan, Wirogunan, Pandeyan, Sorosutan }\end{array}$ \\
\hline 3. & 2 & Resiko sangat tinggi & $\begin{array}{l}\text { Cokrodiningratan, Demangan, Klitren, Sosromenduran, } \\
\text { Ngampilan, Gunungketur, Mantrijeron, Patehan, Prawirodirjan, } \\
\text { Semaki, Muja-Muju, Tahunan, Warungboto, Giwangan, } \\
\text { Rejowinangun, Prenggan }\end{array}$ \\
\hline 4. & 1 & Kurang beresiko & Baciro, Bausasran, Suryodiningratan, Kadipaten, Purbayan \\
\hline
\end{tabular}

Sumber : Hasil Pengolahan Data, 2012
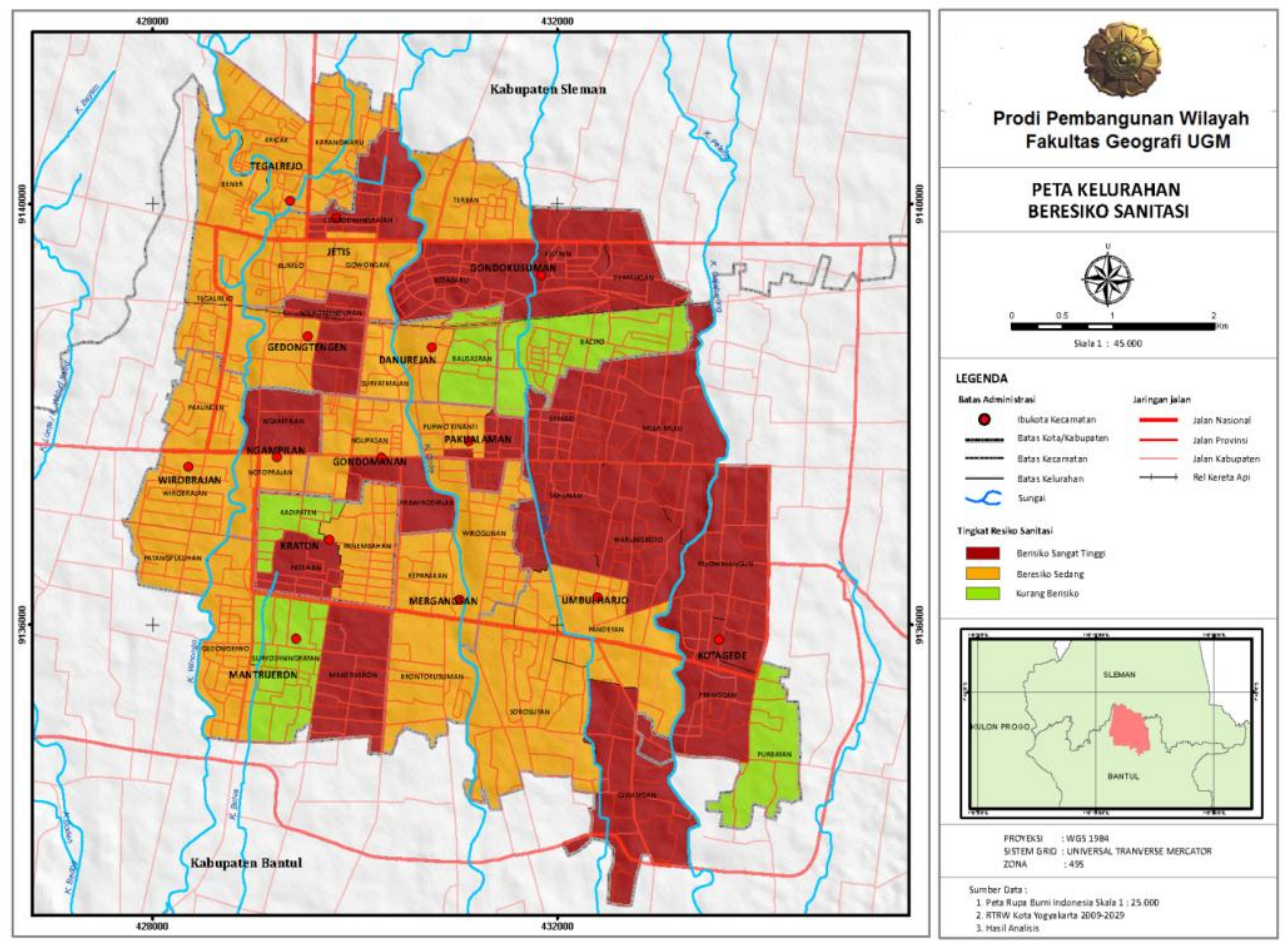

Gambar 13. Peta Area Beresiko Sanitasi Kota Yogyakarta

(Sumber: Analisis Data, 2012)

\subsection{Perencanaan Sanitasi Kota Yogyakarta tahun 2013}

Perencanaan sanitasi dimaksudkan untuk menciptakan kemudahan bagi masyarakat agar dapat mengakses sanitasi layak yang juga merupakan salah satu tujuan dalam Millenium Development Goals (MDGs). Sanitasi jika tidak ditangani dengan serius akan menyebabkan berbagai permasalahan yang dapat menimbulkan berbagai penyakit serta 
munculnya kawasan kumuh. Sebagai contoh permasalahan sampah, produksi sampah yang terus-menerus mengakibatkan terjadinya tumpukan sampah di beberapa TPS di Kota Yogyakarta. Tumpukan sampah tersebut merupakan sumber polusi dan penyakit yang dapat menggangu kesehatan dan kenyamanan warga.

Berdasarkan hasil pengolahan dan pemetaan kondisi sanitasi Kota Yogyakarta, beberapa perencanaan yang dapat dilakukan untuk menumbuhkembangkan kondisi sanitasi yang layak bagi warga. Rencana tersebut terdiri dari perencanaan air limbah, persampahan, dan drainase. Beberapa rencana pengembangan air limbah dibagi ke dalam beberapa program berikut:

1) Program peningkatan sarana dan prasarana sanitasi.

Beberapa kegiatan dalam program ini adalah:

a) Pembangunan IPAL komunal Kelurahan Terban

b) Pembangunan IPAL komunal Kelurahan Ngupasan

c) Pembangunan IPAL komunal Kelurahan Gowongan

d) Pembangunan IPAL komunal Kelurahan Karangwaru

e) Pembangunan IPAL komunal Kelurahan Tegalpanggung

f) Pembangunan IPAL komunal Kelurahan Keparakan

g) Pembangunan IPAL komunal Kelurahan Sorosutan

h) Pemeriksaan polutan air sumur satu bulan sekali

i) Studi IPLT

j) Pembangunan IPAL komunal dan sharing pendanaan dengan masyarakat (SANIMAS)

2) Peningkatan dan pembangunan sarana prasarana saluran air limbah

Beberapa kegiatan dalam program ini adalah:

a) Pembangunan sambungan rumah dan saluran pembawa Terban

b) Pembangunan sambungan rumah dan saluran pembawa Ngupasan

c) Pembangunan sambungan rumah dan saluran pembawa Gowongan

d) Pembangunan sambungan rumah dan saluran pembawa Karangwaru

e) Pembangunan sambungan rumah dan saluran pembawa Ngupasan

f) Pembangunan sambungan rumah Sorosutan

g) Pembangunan sambungan rumah dan saluran pembawa Tegalpanggung

h) Sosialisasi pemeriksaan kondisi septik tank

i) Penambahan jumlah armada truk tinja

Disamping air limbah, direncanakan juga program pengelolaan persampahan. Beberapa rencana pengembangan persampahan dibagi ke dalam beberapa program berikut:

1) Pembersihan sampah

Beberapa kegiatan dalam program ini adalah:

a) Penyapuan jalan dan Pemeliharaan Kebersihan Kota Yogyakarta

b) Pengadaan Gerobak sampah

c) Pengadaan Tempat Sampah

d) Pembuatan percontohan Bank Sampah

2) Pengangkutan Sampah

Beberapa kegiatan dalam program ini adalah:
a) Rehabilitasi TPS permanen
b) Rehabilitasi kontainer sampah
c) Rehabilitasi landasan kontainer sampah
d) Revitalisasi armada truk pengangkut sampah 
e) Pengadaan armada roda tiga pengangkut sampah

f) Pembangunan TPS baru di permukiman dekat sungai

g) Studi penerapan insinerator

h) Studi alternatif pendanaan pengelolaan persampahan dari swasta

i) Review Perda Kota Yogyakarta No 18 Tahun 2002 tentang Pengelolaan Kebersihan (agar mengikuti kondisi dan perkembangan teknologi pengelolaan persampahan)

3) Pengelolaan sampah mandiri

Beberapa kegiatan dalam program ini adalah:

a) Penyediaan sarana pengolahan sampah mandiri

b) Penyediaan alat pencacah sampah organik

c) Pelatihan fasilitator pengelolaan sampah mandiri

d) Pelatihan pengelolaan sampah anorganik

e) Workshop pengelolaan sampah

f) Monitoring dan pendampingan pengelolaan sampah mandiri

g) Penyelenggaraan festival daur ulang sampah

h) Studi karakteristik dan komposisi sampah kota yogyakarta

i) Studi pemanfaatan komposter rumah tangga kota yogyakarta

Selain air limbah dan persampahan, perencanaan pengelolaan drainase juga disiapkan sebagai bagian yang tidak terpisahkan dari pengelolaan sanitasi terpadu. Beberapa program yang direncanakan adalah:

1) Peningkatan dan Pemeliharaan Drainase

2) Perbaikan SAH RW 05 den 06 Kel. Wirogunan

3) Perbaikan SAH RT 10 RW 03 cs Kel. Tegalrejo

4) Perbaikan SAH RT 47 RW 10 Gunungketur

5) Pemeliharaan SAH Tersebar (Insidentil)

6) Peningkatan dan pemeliharaan drainase

7) Pembangunan SAH RT 03 RW 01 Mujamuju

8) Pembangunan SAH JI Raya Gembira Loka RT 19,20 RW 06

9) Pembangunan SAH JI Sisingamangaraja RT 51 RW 14

10) Pembangunan SAH JI Madubronto RW 2, RW 3

11) Pembangunan SAH JI Wiratama, batas kelurahan Pekuncen

\section{Kesimpulan}

Sub sektor sanitasi Kota Yogyakarta meliputi pengelolaan persampahan, limbah dan drainase. Pengelolaan sampah Kota Yogyakarta dilakukan dengan pengangkutan menuju TPA (Tempat Pembuangan Akhir) Piyungan. Sedangkan untuk pengelolaan imbah, penduduk yang rumahnya dilengkapi dengan jamban umumnya telah memiliki tangki septik sebagai tempat pembuangan akhir tinja. Sistem drainase di Kota Yogyakarta masih mengandalkan sistem pembuangan air permukaan ke sungai/anak sungai, baik dari lingkungan permukiman maupun daerah terbangun lain, menuju ke saluran-saluran air hujan kemudian dibuang ke sungai dan akhirnya ke laut. Saluran drainase yang berada di sekitar rumah tangga menggunakan saluran terbuka dan tertutup baik yang dialirkan ke sungai maupun sumur resapan yang telah ada.

Hasil klastering dan studi EHRA menghasilkan tiga area beresiko di Kota Yogyakarta antara lain area kurang beresiko, area beresiko sedang, dan area beresiko sangat tinggi. Hasil kategorisasi menunjukkan bahwa terdapat dua klaster kelurahan yang memiliki resiko sanitasi sangat tinggi, dan hanya satu klaster yang memiliki kategori kurang beresiko. 
Perencanaan sanitasi dilakukan untuk menumbuhkembangkan kondisi sanitasi yang layak bagi warga. Rencana tersebut terdiri dari perencanaan air limbah, persampahan, dan drainase. Perencanaan air limbah meliputi program peningkatan sarana dan prasarana sanitasi dan peningkatan dan pembangunan sarana prasarana saluran air limbah. Perencanaan pengelolaan persampahan meliputi program pembersihan sampah, pengangkutan sampah dan Pengelolaan sampah mandiri. Sedangkan untuk perencanaan drainase adalah program peningkatan dan pemeliharaan sanitasi.

\section{Daftar Pustaka}

Badan Perencanaan Pembangunan Daerah (BAPPEDA) Kota Yogakarta. 2008. Survey Nyata Kebutuhan Sanitasi Kota Yogakarta. Yogyakarta: BAPPEDA Kota Yogyakarta.

Badan Perencanaan Pembangunan Nasional (BAPPENAS). 2010. Laporan Pencapaian

Tujuan Pembangunan Millenium di Indonesia. Jakarta: Badan Perencanaan Pembangunan Nasional.

Damayanthi dkk. 2008. Aspek Sanitasi dan Higiene di Kantin Asrama Tingkat Persiapan Bersama (TPB) Institut Pertanian Bogor. Jurnal Gizi dan Pangan, Maret 20083 (1), hal 22-29.

Harmayani dan Konsukartha. 2007. Pencemaran Air Tanah Akibat Pembuangan Limbah Domestik di Lingkungan Kumuh Studi Kasus Banjar Ubung Sari Kelurahan Ubung. Vol 5 No 2 Agustus 2007, hal $62-108$.

Percepatan Pembangunan Sanitasi Perkotaan (PPSP). 2012. Petunjuk Praktis Penyusunan Buku Putih Sanitasi Kabupaten/Kota. Jakarta: Pokja AMPL.

Percepatan Pembangunan Sanitasi Perkotaan (PPSP). 2012. Metodologi Studi EHRA.

Pokja Sanitasi Kota Yogyakarta. 2012. Laporan Studi Environmental Health Risk Assessment (EHRA) Kota Yogyakarta. Yogyakarta: Bappeda Kota Yogyakarta.

Tim Teknis Pembangunan Sanitasi. 2010. Buku Referensi Opsi Sistem dan Teknologi Sanitasi. Jakarta.

WHO, 2012. Sanitation. http://www.who.int/topics/sanitation/en/. Diakses tanggal 21 Agustus 2012. 